\title{
Hypernatraemic dehydration and breast feeding: a population study
}

\author{
S Oddie, S Richmond, M Coulthard
}

\begin{abstract}
As part of a population based regional review of all neonatal readmissions, the incidence of dehydration with hypernatraemia in exclusively breast fed infants was estimated. All readmissions to hospital in the first month of life during 1998 from a population of 32015 live births were reviewed. Eight of 907 readmissions met the case definition, giving an incidence of at least 2.5 per 10000 live births. Serum sodium at readmission varied from 150 to $175 \mathrm{mmol} / \mathrm{l}$. One infant had convulsions. The sole explanation for hypernatraemia was unsuccessful breast feeding in all cases. The eight cases are compared with the 65 cases published in the literature since 1979. Presentation, incidence, risk factors, pathophysiology, treatment, and prevention are discussed. (Arch Dis Child 2001;85:318-320)
\end{abstract}

Keywords: hypernatraemia; dehydration; breast feeding; newborn; readmissions

Hypernatraemic dehydration has been reported to complicate exclusive breast feeding in 65 cases in the literature. ${ }^{1-26}$ Fits occurred in 17 cases, and substantial lasting morbidity $^{271121}$ and mortality have been reported..$^{22}$ Following a population based review of readmission to hospital in the first 28 days of life, we report on infants presenting with dehydration and hypernatraemia and provide an estimate of the incidence of this condition in the UK.

\section{Methods}

All babies readmitted to any of the 14 hospitals in the former Northern Region before the age of 29 days during the calendar year 1998 were identified by interrogating hospital information departments. Babies reviewed in outpatient clinics, emergency departments, paediatric wards, or day units were not included unless they stayed overnight. Readmissions starting after midnight and before 0900 were included, even if the child was discharged on the date of admission. There were 32015 live births in the Northern Region in 1998.

Information was collected from original hospital notes on the first readmission and the birth episode by a single auditor (SO). The infant's day of birth was considered as day 1 if born before midday and as day zero if born later. A case was included if there was a history of poor feeding, with weight loss that was corrected by fluid replacement, and serum sodium was measured at 150 or greater.
Table 1 Cases presenting with hypernatraemia on readmission

\begin{tabular}{llclll}
\hline $\begin{array}{l}\text { Body } \\
\text { wt } \\
(g)\end{array}$ & $\begin{array}{l}\text { Day of } \\
\text { postnatal } \\
\text { discharge }\end{array}$ & $\begin{array}{l}\text { Day } \\
\text { readmitted }\end{array}$ & $\begin{array}{l}\text { Wt } \\
\text { loss } \\
(\%)\end{array}$ & $\begin{array}{l}\text { Max } \\
{[\text { Na] }} \\
\text { (mmol/l) }\end{array}$ & $\begin{array}{l}\text { Fully breast fed } \\
\text { on second } \\
\text { discharge }\end{array}$ \\
\hline 4220 & 7 & 10 & 15 & 151 & No \\
3100 & $\begin{array}{l}\text { Home } \\
\text { delivery }\end{array}$ & 6 & 16 & 160 & Yes \\
3720 & 2 & 7 & 17 & 150 & No \\
3495 & 3 & 7 & 18 & 152 & No \\
2670 & 2 & 6 & 19 & 156 & No \\
2780 & 3 & 6 & 20 & 163 & $?$ \\
3590 & 2 & 8 & 26 & 157 & No \\
2350 & 4 & 10 & 27 & 175 & No \\
& & & & &
\end{tabular}

\section{Results}

From a population of 32015 live births, 1897 $(5.9 \%)$ possible readmissions were identified. Notes were traced and examined for 1716 $(90.5 \%)$ of these and 907 were true readmissions. Notes on 181 cases from the original list could not be located. If the notes found were representative of those missing, we retrieved about $90 \%$ of all true readmissions. If all the 181 missing notes were true readmissions, then we have reviewed the notes of $83 \%$ of readmissions, and if none were true readmissions we have reviewed $100 \%$. It is likely that the true figure lies between these two extremes, and that it is near to $90 \%$.

Thirty four readmissions had lost more than $10 \%$ of their birth weight, and sodium concentrations were recorded in all but four. Only eight had a serum sodium of 150 or greater. All eight were breast fed. These babies are the subject of this report. They presented at a median day 7 (range 6-10, see table 1). All were the first babies managed at home by their mothers and all were born at term (median 39.6, range 37-41 weeks). Two were below $3000 \mathrm{~g}$ at birth. A concerned midwife referred four infants for admission. It was unclear who initiated readmission in the remaining four cases. There was concern about jaundice in one case, vomiting in two cases, and poor feeding or poor weight gain in four. None had diarrhoea.

All lost at least $15 \%$ of their birth weight. One may have had fits. She had a serum sodium of $175 \mathrm{mmol} / 1$ at presentation, having lost more than $25 \%$ of her birth weight. She experienced a reduction in serum sodium from 175 to $170 \mathrm{mmol} / \mathrm{l}$ within eight hours of readmission to hospital. Cycling movements were noted which settled spontaneously six hours after readmission. Electroencephalography was not performed.

By 1 year, no baby was found to have a disorder that might have explained the hypernatraemia and none had died. In only four cases did the notes suggest that hypernatraemia had been recognised as a significant concern. Only 


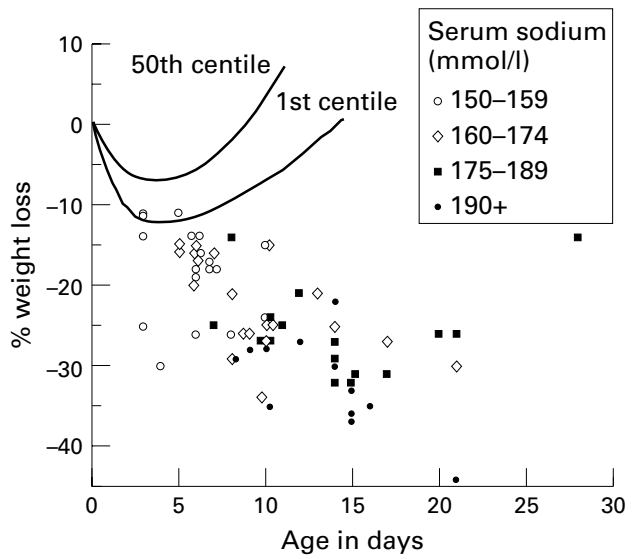

Figure 1 Percentage weight loss, serum sodium, and age at presentation in breast fed babies with dehydration and hypernatraemia (current report and literature ${ }^{1-26}$ ). Centile lines for weight loss constructed by Dr EN Hey using seria weights from a sample of some 200 breast fed term infants born at the Princess Mary Maternity Hospital, Newcastle-upon-Tyne in the 1960s.

one baby was breast fed at subsequent discharge.

Breast feeding rates in the Northern Region are low, being approximately $35 \%$ at first hospital discharge. First time mothers represent $32 \%$ of births. The incidence of hypernatraemic dehydration secondary to breast feeding difficulty of 2.5 per 10000 live births can therefore be estimated to represent rates of 7.1 per 10000 breast fed newborns, or 22.3 per 10000 breast feeding first time mothers. Cases may have been missed because they occurred in infants before initial discharge home, ${ }^{23}{ }^{24}$ or because appropriate investigations were not done. These figures therefore represent a minimum incidence.

\section{Discussion}

Hypernatraemic dehydration of breast fed infants has been described in 65 infants in 26 reports since $1979 .{ }^{1-26}$ Serious complications are reported, including fits, disseminated intravascular coagulation, multiple cerebrovascular accidents, and need for amputations. ${ }^{2} 71121$

In many cases the mother has been of higher than average educational attainment, with no practical experience of breast feeding but a strong desire to breast feed. ${ }^{14720}$ Almost all cases have been to primiparous mothers; in very few has the mother successfully breast fed a previous baby. ${ }^{17}$ Occasional infants have had predispositions to feeding problems, such as Down's syndrome ${ }^{19}$ or a cleft palate. ${ }^{4}{ }^{26}$ Some mothers have had inverted nipples. ${ }^{62}$ Four cases occurred in hospital. ${ }^{23}{ }^{24}$ However, most were normal term babies cared for by first time mothers at home.

Presentation is usually at around 10 days of age (range 3-21 days). ${ }^{1-26}$ Parents characteristically have little appreciation of their infant's illness and may present after routine review, apparently unrelated consultation, or with an acute deterioration. ${ }^{1}{ }^{4} 816$

The typical history is of an infant who is either excessively passive $e^{13-791626}$ or who cries unusually. ${ }^{14}$ Some parents have been reassured by family or professionals. ${ }^{16}{ }^{20}$ Urine output is low but may not be appreciated as such. ${ }^{8}$ An absence ${ }^{182026}$ of the expected increase in stool frequency in the first few days of life is sometimes noted. ${ }^{27}$

Clinical examination is often striking, with significant weight loss and an appearance which varies from alert and hungry, to moribund. Complications, most notably fits, characteristically occur during treatment rather than at presentation. ${ }^{4691518}{ }^{23}$ Death is caused by cerebral oedema or infarction.

High sodium concentrations in the breast milk have been noted and considered causal. ${ }^{3}{ }^{14}$ However, this may just be a marker of poor interaction between baby and breast, ${ }^{28}$ as suggested by a report of a disparity between sodium measurements in milk from one woman's left and right breasts. ${ }^{20}$ Volumes of breast milk, when reported, are strikingly low. ${ }^{3} 1314$ The poor satiety achieved by some of these infants, their poor urine output, and poor stool output all suggest that the problem is water deprivation, with secondary accumulation of sodium in an attempt to maintain circulating volume. In support of this hypothesis, a baby presented to one of the authors (SR) at 6 days of age having lost $20 \%$ of her birth weight and with a serum sodium of $158 \mathrm{mmol} / \mathrm{l}$. Though she was bottle fed, no milk ever reached her stomach because she had oesophageal atresia.

In the 1970 s gastroenteritis with hypernatraemia of relatively acute onset ${ }^{29}$ was a significant cause of mortality and neurological sequelae in infants. ${ }^{30}$ Intake of excess sodium in inappropriately prepared formula milks was blamed at the time, ${ }^{29}$ but a more plausible explanation is that continued feeding with milk after the onset of diarrhoea resulted in the delivery of a protein rich solution to the colon which, after digestion by colonic bacteria, produced a considerable osmotic load. ${ }^{31}$ The mean duration of symptoms was typically 2.5 days $^{32}$ or 4 days. $^{29}$ Animal experiments ${ }^{33}$ and some human data ${ }^{29} 34$ show that brain damage with acute hypernatraemia occurs as a result of brain cell shrinkage as the plasma osmolality rises too quickly for the protective mechanisms to take effect.

Hypernatraemia in breast fed infants is crucially different from that associated with gastroenteritis as it develops over a longer period, allowing the central nervous system to adjust to the increasing osmolality. In our cases the median time of presentation was day 7; it was day 12 in the cases from the literature (fig 1).

Slow onset hypernatraemia should be corrected slowly. ${ }^{18}$ Central nervous system cells can maintain intracellular volume despite slowly increasing plasma osmolality by manufacturing intracellular osmotically active substances (amino acids, trimethylamines, myoinositol). Rapid correction of plasma osmolality without allowing sufficient time for the brain cells to dismantle these defences causes cell swelling (cerebral oedema), disruption of fine neuronal connections, and consequent brain damage. The speed with which the situation can be safely corrected is proportional to the speed with which it arose. 
Magnetic resonance imaging spectroscopy in an infant with hypernatraemia found these "idiogenic osmoles" producing a calculated excess intracellular osmotic pressure of 17 $\mathrm{mOsm} / \mathrm{kg}{ }^{35}$ The concentration fell as serum osmolality declined, but did not return to normal until 36 days after electrolyte correction was started.

In the published literature 17 infants had seizures, of whom 14 had a serum sodium above 165; only one was below 175 (the sodium concentration was not given in the remaining three infants). In 12 the convulsions occurred after treatment started. This is commented on in some reports. ${ }^{49151823}$ Seizures may have been related at least as much to the treatment of the hypernatraemia, as to the hypernatraemia itself. In many cases the hypernatraemia is not extreme, and therapy may be less critical.

When discussing this condition with midwives we encountered considerable resistance to routine weighing of breast fed babies for fear that documenting weight loss would lead to abandonment of breast feeding. Some weight loss during the first week of life is physiologi$\mathrm{cal}^{36}$ and this information should be easily communicated to mothers. Exactly how much is "normal" is uncertain. Ensuring practical support for primiparous breast feeding mothers, both in hospital and at home, should prevent this problem occurring. Weighing of their infants in the first week of life, as suggested by the American Academy of Pediatrics working group on breast feeding, ${ }^{37}$ should allow early identification of those where breast feeding is not progressing adequately.

Sam Oddie is a member of the Tyne and Wear Health Action Zone breast feeding subgroup. We are indebted to Dr EN Hey for advice and for the data on normal weight loss in term breas fed babies shown in fig 1 .

1 Clarke TA, Markarian M, Griswold W, Mendoza S. Hypernatremic dehydration resulting from inadequate breastfeeding. Pediatrics 1979;63:931-2

2 Arboit JM, Gildengers E. Breastfeeding and hypernatremia. f Pediatr 1980;97:335-6.

3 Anand SK, Sandborg C, Robinson RG, Lieberman E. Neonatal hypernatremia associated with elevated sodium concentration of breast milk. F Pediatr 1980;96:66-8.

4 Roddey OF, Martin ES, Swetenburg RL. Critical weight loss and malnutrition in breastfed infants. Am F Dis Child 1981;135:597-9.

5 Jaffe KM, Kraemer MJ, Robison MC. Hypernatremia in breastfed newborns. West f Med 1981;135:54-5.

6 Ernst JA, Wynn RJ, Scgreiner RL. Starvation with hypernatremic dehydration in two breast-fed infants. $\mathcal{F} \mathrm{Am}$ hypernatremic dehydration
Diet Assoc 1981;79:126-30.

7 Rowland T. Malnutrition and hypernatremic dehydration in Rowland T. Malnutrition and hypernatremic

8 Rushton AR, Lambert GP, Katcher AL, Frangakis D. Dehydration in a breastfed infant. $\mathcal{F} A M A 1982 ; 248: 646$.
9 Ghishan FK, Roloff JS. Malnutrition and hypernatremic Ghishan FK, Roloff JS. Malnutrition and hypernatremic dehydratic

10 Escribano MPM, Sirvent JS, Gil JM, et al. Deshidratación hipertónica con lactancia materna. An Esp Pediatr 1984;21: 774-6.

11 Clarke AJ, Sibert JR. Hypernatraemic dehydration and necrotizing enterocolitis. Postgrad Med f 1985;61:65-6.

12 Mercier JC, Outin S, Paradis K, et al. Allaitement maternel et déshydration hypernatrémique: etude de 3 observations. Arch Fr Pediatr 1986;43:465-70.

13 Thullen JD. Management of hypernatremic dehydration due to insufficient lactation. Clin Pediatr 1988;27:370-2.

14 Peters JM. Hypernatremia in breastfed infants due to Peters JM. Hypernatremia in breastfed infants due to
elevated breastmilk sodium. F Am Osteopath Assoc 1989;89: elevated b

15 Lohr J, Springate J, Feld L. Seizures during correction of hypernatremic dehydration in an infant. Am $\mathcal{F}$ Kidney Dis $1989 ; \mathbf{1 4}: 232-5$

16 Heldrich FJ, Shaw SS. Case report and review of the literature, hypernatremia in breast-fed infants. Maryland Medical fournal 1990;29:475-8.

17 Sofer S, Ben-Ezer D, Dagan R. Early severe dehydration in young breast-fed newborn infants. Isr F Med Sci 1993;29: $85-9$.

18 Molteni KH. Initial management of hypernatremic dehydration in the breastfed infant. Clin Pediatr 1994;33:731-

19 Kini N, Zahn S, Werlin SL. Hypernatremic dehydration in breast-fed infants. Wis Med f 1995;94:143-5.

20 Chilton LA. Prevention and management of hypernatremic dehydration in breastfed infants. West 7 Med 1995;163: $74-6$.

21 Cooper WO, Atherton HD, Kahana M, Kotagal UR. Increased incidence of severe breastfeeding malnutrition and hypernatremia in a metropolitan area. Pediatrics 1995; 96:957-60.

22 Kaplan JA, Siegler RW, Schmunk GA. Fatal hypernatraemic dehydration in exclusively breast-fed newborn infants due to maternal lactation failure. Am 7 Forensic Med Pathol 1998;19:19-22.

23 Chaudhary R, Twaddle S, Levi R, Haque K. Hypernatremic dehydration in breast-fed infants. Paediatrics Today 1998;6: 85-7.

$24 \mathrm{Ng}$, PC, Chan HB, Fok TF, et al. Early onset of hypernatraemic dehydration and fever in exclusively

25 Korkmaz A, Yigit S, Firat M, Oran O. Cranial MRI in neonatal hypernatraemic dehydration. Pediatr Radiol 2000;30: 323-5.

26 Livingstone VH, Willis CE, Abdel-Wareth LO, et al. Neonatal hypernatremic dehydration associated with breastfeeding malnutrition: a retrospective survey. CMAF 2000; $162: 647-52$

27 Illingworth R. The normal child. London: Churchill Livingstone, 1991

28 Morton J. The clinical usefulness of breast milk sodium in the assessment of lactogenesis. Pediatrics 1994;93:802-6.

29 Chambers TL, Steel AE. Concentrated milk feeds and their relation to hypernatraemic dehydration in infants. Arch Dis Child 1980;33:637-63.

30 Macaulay D, Watson M. Hypernatraemia in infants as a cause of brain damage. Arch Dis Child 1967;42:485-91

31 Hirschhorn N. The treatment of acute diarrhea in children: an historical and physiological perspective. Am $\mathcal{F}$ Clin Nutr 1980;33:637-63.

32 Kahn A, Blum D, Casimir G, Brachet E. Controlled fall in natremia in hypertonic dehydration: possible avoidance of rehydration seizures. Eur $\mathcal{F}$ Paediatr 1981;135:293-6.

33 Sotos JF, Dodge PR, Meara P, Talbot NB. Studies in experimental hypertonicity. 1. Pathogenesis of the clinical syndrome, biochemical abnormalities and cause of death. Pediatrics 1960;26:925-38.

34 Finberg I, Kiley J, Luttrell CN. Mass accidental poisoning in infancy. $\mathcal{F} A M A$ 1963;184:187-90.

35 Lee JH, Arcinue E, Ross BD. Brief report: Organic osmolytes in the brain of an infant with hypernatraemia. $N$ Engl f Med 1994;331:439-42.

36 Maisels MJ, Gifford K. Breast-feeding, weight loss, and jaundice. $\mathcal{F}$ Pediatr 1983;102:117-18.

37 American Academy of Pediatrics. Breastfeeding and the use of human milk. Pediatrics 1997;100:1035-9. 